\title{
The Designation of Points on Maps
}

\section{Author(s): C. F. Close}

Source: The Geographical Journal, Vol. 52, No. 4 (Oct., 1918), pp. 274-276

Published by: geographicalj

Stable URL: http://www.jstor.org/stable/1779903

Accessed: 20-06-2016 23:20 UTC

\section{Your use of the JSTOR archive indicates your acceptance of the Terms \& Conditions of Use, available at}

http://about.jstor.org/terms

JSTOR is a not-for-profit service that helps scholars, researchers, and students discover, use, and build upon a wide range of content in a trusted digital archive. We use information technology and tools to increase productivity and facilitate new forms of scholarship. For more information about JSTOR, please contact support@jstor.org.

The Royal Geographical Society (with the Institute of British Geographers), Wiley are collaborating with JSTOR to digitize, preserve and extend access to The Geographical Journal 
wood gives a summary of such descriptive names used in Freshfield's ' Round Kangchenjunga,' along with Tibetan equivalents, in a supplement to that book. There would naturally in many cases be several peaks with the same designation, but this need cause little difficulty if the name of the Degree Sheet were employed for distinction. In Scotland there are often several mountains with the same name, e.g. Ben More. The name when unqualified indicates the highest peak (Perthshire). In the other cases a qualifying local name is applied, e.g. Ben More of Assynt, Ben More in Mull.

Lastly, might I be permitted in the interests of Himalayan nomenclature to venture a remark regarding the statement in connection with Kanchenjunga in Burrard and Hayden's volume, that the most recent term applied, namely Kinchinjunga, should be adopted, although probably incorrect etymologically, because "uniformity in spelling is of more importance to geographers than correctness." I must take the liberty of disagreeing in this respect, as I fail to see that there is any excuse for mutilating a good nameand Kangchenjunga is an admirable designation-so that its meaning becomes unintelligible. Presumably it would be possible to secure both uniformity and etymological exactitude. Kinchinjunga is obscure because the first two syllables are derived from the Tibetan words "Kang," snow, and "chen," great. Kangchenjunga therefore seems etymologically to be by far the better term. Dr. Freshfield, in his book on the circuit of the mountain, states that he selected the name from fourteen variants. The selection of one definite name is certainly important. In 1903 three of the names which had been used for the mountain, namely Kangchenjunga, Kangchanjunga, and Kanchinjinga, appeared simultaneously in different survey maps.

Might one suggest that all Asiatic place-names should be submitted before adoption to linguistic experts, who would determine the etymology when possible, and crystallize the spelling and pronunciation.

A. M. Kellas.

[We are glad to publish Dr. Kellas' letter as the first contribution to that discussion of Sir Sidney Burrard's note which we invited on its publication.

We would add that the present Director-General found himself confronted with an accomplished fact in the case of the name for Mount Everest, and cannot well be held responsible for the single exception to the principle upon which he has acted.-ED. G. F.]

\section{The Designation of Points on Maps.}

I have read with much interest the article in the September number of the Fournal on "The Identification of Peaks in the Himalaya," and feel sure that there will be a general agreement that it is desirable to give a name to each degree chart, as proposed by Sir Sidney Burrard, and think that, on the whole, the system proposed by him is simple and practical. But there seems to be some doubt as to the actual procedure followed in giving the peaks numbers, and I venture to suggest a possible system which would not only apply to this particular problem but might also have some utility in other cases.

The suggested system is the following: Imagine each side of a map to be divided into three equal portions, and join the opposite corresponding divisions by straight lines. Then the map is partitioned off into nine approximately 
equal cells. Number these cells as shown. Now, suppose that each of the cells is similarly divided :

FIRST ORDER CELLS:

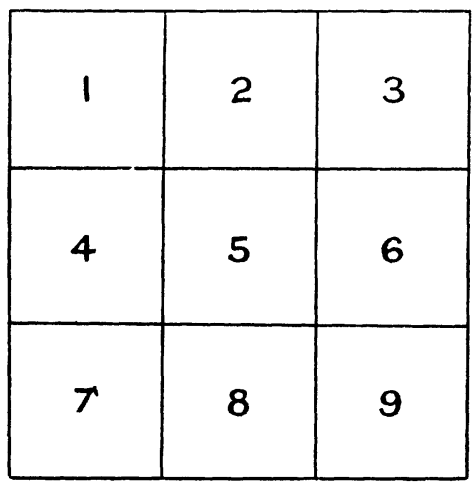

SECOND ORDER CELLS

\begin{tabular}{|l|l|l|l|l}
\hline 1 & 2 & 3 & & \\
\hline 4 & 5 & 6 & 2 & 3 \\
\hline 7 & 8 & 9 & & \\
\hline & & 5 & 6 \\
& 4 & 5 & \\
\hline & & & &
\end{tabular}

and let each second-order cell be similarly divided, thus :

THIRD ORDER CELLS.

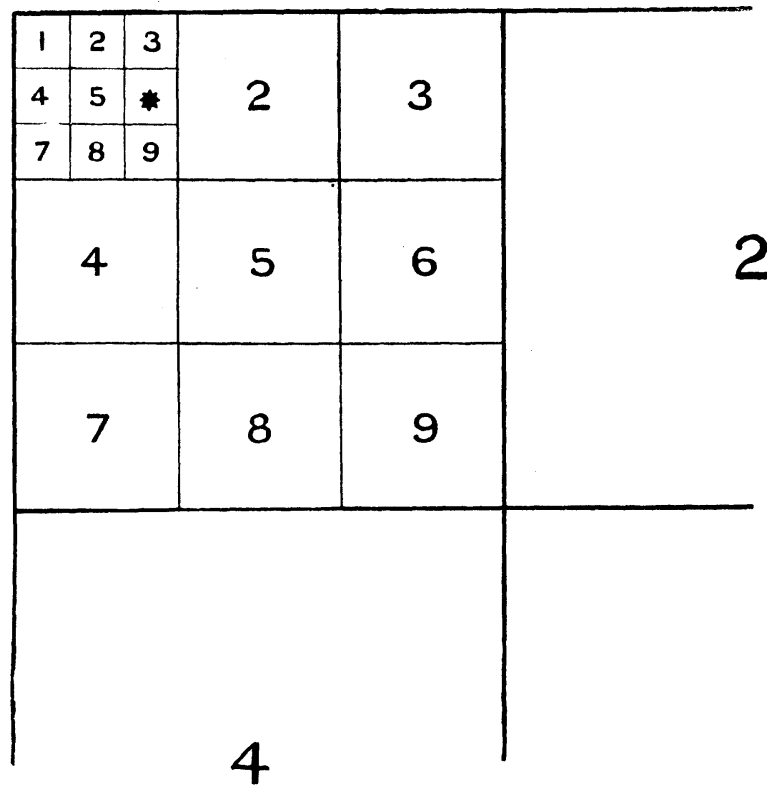

and so on.

Then let us, by convention, describe a cell of any order by a number of which the first figure is the number of the first-order cell in which it lies, the second figure the number of the second-order cell, and so on. Thus the cell marked * in the above figure is 116 . The map is thus imagined to be divided into $9^{n}$ cells, where $n$ is the number of orders used. In the case of three order 
the number of cells is 729 , and if a degree sheet is about 4200 square miles in area, the area of each cell will be a little less than 6 square miles. With two orders the area of each cell will be 50 square miles; with four orders, about $\frac{2}{3}$ square mile, etc. For the case of the Himalayan peaks a $2 \cdot$ order cell would no doubt be sufficient.

This system can conveniently be used where areas require identification, and, in the case of mountains, it is sometimes not only the highest peak that requires locating but the mountain itself, or the group to which it belongs.

But sometimes it is necessary to determine, by some system, the position of an actual point. This can be done, of course, by co-ordinates, but only to the degree of accuracy allowed by the unit of measure of the co-ordinates. With the same kind of accuracy the cell system can be employed if we use the symbol for a recurring number; $\dot{4}$, for instance, represents $444 \ldots$ ad infinitum, and by our convention this implies cell inside cell, always approach. ing the middle point of the left side of the map, until at the limit this point is reached. $\dot{4}$ therefore means the middle point of the left side of the map.
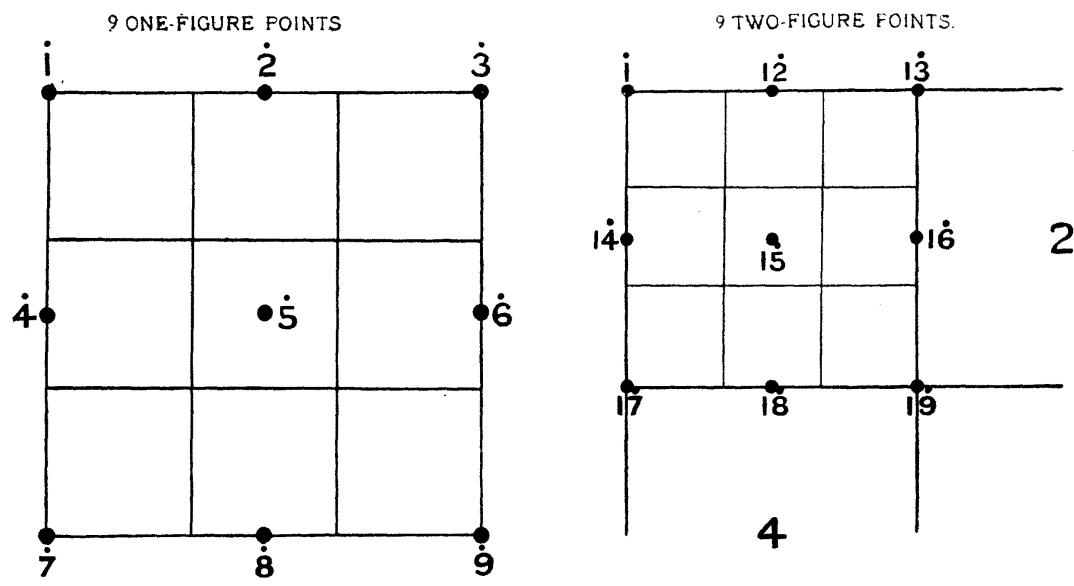

In the same way $\mathrm{I} \dot{4}$ means the middle point of the left side of cell $\mathrm{I}$, and 124 means the middle point of the left side of cell 2 of cell $\mathrm{I}$, and so on.

There are also "two-dot" numbers of two or more digits. Of the former, such as 24 , there are 72 with different digits, or 81 if we include the numbers ii, etc., which are equivalent to the "one-dot" numbers $i$, etc. The two-dot points, such as $i \dot{2}, 13, \dot{6} \dot{2}, \dot{5} \dot{4}$, etc., divide the map each way into eighths, and are at the corners of 64 similar spaces.

The cells and points can both be used if required. Some of the points can be described in more than one way; thus $1 \dot{9}$ is the same as $2 \dot{7}$, or $4 \dot{3}$, or $5 \dot{\mathrm{I}}$. It might be as well always to use the description beginning with the smallest number. But each description is definite, and the use either of cells or points can be applied to any four-sided map.

Southampton, I3 September 1918.

C. F. Close. 